Camille Logeay, IMK

Silke Tober, IMK

\title{
Hysteresis and Nairu in the Euro Area
}




\title{
Hysteresis and Nairu in the Euro Area
}

\author{
Camille Logeay \\ Macroeconomic Policy Institute \\ (IMK) \\ Camille-Logeay@boeckler.de
}

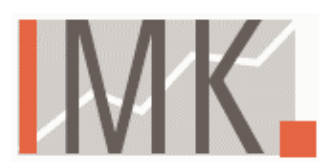

\author{
Silke Tober \\ Macroeconomic Policy Institute \\ (IMK) \\ Silke-Tober@boeckler.de

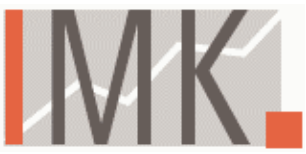

This version: July 2005

\begin{abstract}
This paper analyses the Nairu in the Euro Area and the influence that hysteresis had on its development. Using the Kalman-filter technique we find that the Nairu has varied considerably since the early seventies. The Kalman-filter technique is applied here using explicit exogenous variables. In order to test for hysteresis, the dependence of the Nairu on actual unemployment and long-term unemployment is estimated and found to be significant for the Euro Area and Germany respectively. The existence of hysteresis effects implies the possibility of a long-run non-superneutrality of monetary policy.
\end{abstract}

JEL: C32, E32, E52

Keywords: Nairu, hysteresis, Kalman Filter, Phillips curve, superneutrality.

\section{Introduction}

The significant increase in the unemployment rate in Europe since the early 1970s did not occur gradually but in three big steps. In the United States similar upward jumps 
in the unemployment rate can be observed, in contrast to Europe, however, subsequent years always saw a decline in unemployment. Whereas shocks are widely held to be responsible for the large increases in unemployment in both regions the question still remains what caused unemployment to remain relatively high in the Euro Area.

By using a state-space model to estimate the Nairu in the Euro Area since 1975 and to gauge the presence of hysteresis we hope to contribute to this debate. There is ample evidence that institutional changes in the early seventies contributed to the increase in the Nairu and thereby also pushed up actual unemployment. However, there seem to be limits to what these factors can explain (Blanchard and Katz, 1997, p. 68 and Machin and Manning, 1999, p. 3107). Blanchard and Wolfers (2000), for example, argue that:

"...many of these institutions were already present when unemployment was low (and similar across countries), and, while many became less employment-friendly in the 1970 s, the movement since then has been mostly in the opposite direction. Thus, while labour market institutions can potentially explain cross country differences today, they do not appear able to explain the general evolution of unemployment over time."

(Blanchard and Wolfers 2000, p. 2)

Part of the literature views monetary policy as a factor that affects long-term unemployment. ${ }^{1}$ There is no doubt that the restrictive monetary policy in the late seventies as well as the early eighties and nineties played a big role in the increase of the unemployment rate. ${ }^{2}$ Whether this effect was only of a short-term nature - thus not affecting the Nairu - is however quite controversial.$^{\frac{3}{3}}$ If monetary policy gives rise to hysteresis in labour markets and thereby changes the effective labour supply, its short-run effects may extend to the long run.

The novel approach of applying the Kalman-filter technique with an explicit exogenous variable allows us to quantify the effect of changes in this variable on the Nairu. We find that the lagged unemployment rate (Euro Area) and the long-term unemployment rate (Germany) have a significant effect, which indicates the presence of

${ }^{1}$ Cf. Ball and Mankiw (2002), Ball (1999), Blanchard and Katz (1997) as well as Fitoussi, Jestaz, Phelps, and Zoega (2000), who relate the marked increase in unemployment and the fact that it remained high to the restrictive stance of monetary policy in Europe.

${ }^{2}$ Modern monetary policy is based on the notion that money is not neutral in the short term. Nominal rigidities give rise to short-term non-neutrality; cf. Clarida, Galí, and Gertler (1999), McCallum (2001), Mankiw (1985), Akerlof, Dickens, and Perry (2000). In the short term monetary policy is thought to have an effect on real interest rates, aggregate demand and inflation. Unemployment is the key variable through which monetary policy affects inflation (Layard, Nickell, and Jackman 1991, p. 13).

${ }^{3}$ Contrary to the mainstream view, the view that monetary policy has long-term real effects is put, for example, by Cross (1995) and Ball (1999). 
hysteresis. The significant presence of hysteresis implies that any factor that causes unemployment to stay high for a prolonged period causes an increase in the Nairu. It follows from this that a restrictive monetary policy stance maintained over a longer period of time gives rise to hysteresis in the labour market and thereby affects the level of real economic activity beyond the short term.

The remainder of the paper is structured as follows: The next section provides an overview of the literature. Section 3 presents the outcome of the Kalman-filter regression of the Euro-Area Nairu using lagged unemployment rate as an explicit exogenous variable for the Nairu, as well as a corresponding regression for Germany using longterm unemployment as an exogenous variable. In section 4 we conclude by placing these results into the larger macroeconomic context and discussing the role of monetary policy.

\section{Review of the literature and empirical tests of hys- teresis}

The term hysteresis, taken from physics, refers to the condition that equilibria are pathdependent. This term is not always clearly distinguished from the term persistency which implies that the original equilibrium will be reestablished given a sufficiently long period of time. There are two reasons why we do not find it necessary to distinguish between a high degree of persistence and hysteresis in the present context. First, it is the medium-term Nairu that appears to be most policy-relevant. Second, given uncertainty in economic development persistency and hysteresis may be indistinguishable because effects, which would only be persistent in models with perfect knowledge, may actually affect the equilibrium position (Katzner 1993, p. 343f.).

Hysteresis can have different causes. ${ }^{4}$ Its main aspect, however, is that the number of long-term unemployed persons rises and that the latter exert less of an influence on labour market developments and on wages in particular than do the short-term unemployed. There are several reasons why the long-term unemployed have a hard time finding a job:

- The human capital of the unemployed tends to diminish over time. If the productivity of the long-term unemployed falls below their reservation wage or wages are set by insiders the long-term unemployed will remain unemployed (Blanchard and Summers, 1991 and Pissarides, 1992).

\footnotetext{
${ }^{4}$ For a survey on hysteresis see Røed (1997).
} 
- Testing of potential employees is costly. Therefore employers rank potential employees according to the frequency and duration of unemployment spells and favour those with less occurrences of unemployment (Lockwood, 1991 and Blanchard and Diamond, 1994).

- Unemployed persons lose contact to those employed, inter alia because they lack sufficient financial resources to participate in certain social activities or because they feel stigmatised. As a consequence they do not even find out about some job offers and are not considered for some jobs. Machin and Manning (1999, p. 3120) found that about one third of all jobs in the UK are filled with friends and relatives of those already employed in the firm. This is a cost effective way of hiring since it is unlikely that an employee will put forth someone unqualified to do the job.

- A long period of high unemployment can raise the social acceptance of unemployment which could increase the reservation wage of the unemployed (Lindbeck 1995).

- Rising long-term unemployment increases the political pressure to implement public job creation schemes which in turn may increase unemployment by reducing the negative aspects of unemployment (Blanchard and Katz 1997, pp. 68-69); on the other hand, they tend to reduce the Nairu by preserving the human capital of the persons involved.

If for the reasons cited above the long-term unemployed are not competition for those holding a job, they do not exert downward pressure on wages. $[$ ] This can be shown within the efficiency-wage model. The main hypothesis of this approach is that wages are set at a level inducing workers to be highly productive (Shapiro and Stiglitz 1984). This level is dependent on the job prospects in case of job loss. The better the job prospects, the higher are efficiency wages. If the long-term unemployed are not seen as competition for the employed only short-term unemployed figure in the job prospects and the effect that the long-term unemployed might have on wages disappears.

A further mechanism that may cause hysteresis (or persistence) in unemployment during economic downturns (and vice versa in upswings) is the downward adjustment of the capital stock which reduces labour demand given limited factor substitution.

\footnotetext{
${ }^{5}$ Many studies on the UK find empirical evidence that only short-term unemployed not however long-term unemployed individuals have an influence on the wage bargaining process; cf. Machin and Manning (1999) and the references cited therein.

6 "The final persistence mechanism operates though the capital stock. [...] suppose there is an increase in wage pressure that shifts the wage-setting schedule, WW, up. Equilibrium employment falls. However the intersection of medium-run labour demand, NN, with WW now lies above the long-
} 
Multiple equilibria may furthermore result from increasing returns to scale ${ }^{7}{ }^{7}$ high firing costs and the degree of labour market tightness (Røed 1997, pp. 401ff.).

The standard model of modern macroeconomics can serve as a backdrop for an analysis with hysteresis if it is slightly modified in the determination of potential output to allow for hysteresis in the labour markets. ${ }^{\frac{8}{6}}$ With this modification temporary shocks may affect the level of potential output and thereby the economy's growth path (albeit not its slope). Take the example of monetary policy increasing real interest rates to reduce inflation. This causes unemployment to rise. If real interest rates are not lowered once unemployment has started to rise, then unemployment spells will last relatively long and the number of long-term unemployed will increase. If the latters' human capital diminishes or the history of unemployment reduces the ability to find a new job, the effective labour supply declines (the Nairu increases). As a result labour market equilibrium will now involve a lower level of employment. If hysteresis is a significant phenomenon, then sustained monetary restriction will affect the Nairu. We do not here attempt to quantify the latter effect.

Empirical tests of hysteresis are primarily based on univariate unit root tests but also make use of cointegration tests, changing adding lagged unemployment to the wage-price-system, Markov-switching and Kalman-filter techniques as well as microeconomic tests. Unit root tests, although the most popular, have the greatest drawback in that they presuppose a certain invariance of the institutional structure of the labour market. If, however, the unit root is caused by structural change, the unemployment rate will be integrated of order 1 without in any way supporting the hypothesis of hysteresis, since actual unemployment will follow movements in the Nairu rather than the other way around. There is ample evidence for hysteresis.

Based on the panel unit root test developed by Im, Pesaran, and Shin (2003), LeónLedesma (2002) tests for unit roots in the United States and the European Union. He finds strong evidence in case of the latter and weak evidence in the case of the former. This approach is questionable for the reason cited above.

León-Ledesma and McAdam (2004) use the Perron test in addition to the ADF-test to test for hysteresis in the ten new EU-countries and find that controlling for structural

run labour demand schedule; $\mathrm{NN}^{*}$, along which capital is allowed to vary. The mechanism that brings the economy back to long-run equilibrium is capital decumulation which shifts NN in until NN, NN*, and the new WW curves all intersect at the same point." (Bean 1997, p. 93)

${ }^{7}$ In the face of increasing returns to scale multiple equilibria may exist either because of high entry costs (Weitzman 1982) or competing wages and profit claims which in the aftermath of shocks result in very modest wage claims that in turn preclude firms from fully taking advantage of increasing-returns technology (Røed 1997, p. 404).

${ }^{8}$ This standard four-equation model is found in Clarida, Galí, and Gertler (1999), see also McCallum (2001), Mankiw (2001) and Taylor (1997). Mankiw (2001) shows one way of modifying the equation for potential output to allow for hysteresis in the labour markets. 
breaks leads to a rejection of the hysteresis hypothesis. These findings are supported by a corresponding panel analysis. The drawbacks above apply to these analyses as well. Furthermore it is difficult to distinguish between hysteresis and transition effects. The authors then go on to interpret hysteresis in terms of multiple equilibria rather than random walks as suggested by Amable, Henry, Lordon, and Topol (1995). They apply the Markov-switching technique and generally find two states with a high persistency of unemployment: a low-unemployment regime and a high unemployment regime, thus supporting the hypothesis of hysteresis.

In contrast, Salemi (1999) using the Kalman-filter technique does not find evidence for hysteresis in the United States. As in our approach, Salemi simultaneously estimates the Nairu using exogenous explanatory variables and the wage-setting pricesetting system. He tests for hysteresis by testing whether the coefficient of the lagged natural rate of unemployment is 1 in the natural rate equation. Jaeger and Parkinson (1994) apply the Kalman filter technique to British, Canadian, German and U.S. data and come up with significant hysteresis effects in the case of Germany and the United Kingdom.

Johansen (1995) test for cointegration between the unemployment rate and wage level, on the one hand, and between the unemployment rate, long-term unemployment and the wage level, on the other, and find cointegration in both cases with long-term unemployment and the wage level being positively correlated.

Other studies such as Layard, Nickell, and Jackman (1991) test for the first difference of the unemployment rate in the wage-setting price-setting systems, i.e. for the significance of lagged unemployment in the Nairu equation, and find strong evidence of hysteresis for Europe albeit not for the United States. The microeconomic studies, surveyed by Røed (1997) and Layard, Nickell, and Jackman (1991), have mixed results and several methodological problems as pointed out by Røed (1997).

We find the state-space modelling strategy with the Kalman filter more appropriate than the other methods. Unlike the unit-root approach it allows for progressive structural change and in contrast to the cointegration analysis it is not necessary to fully specify the determinants of the Nairu. The latter is of particular importance when factors such as institutional variables are involved that are difficult to measure.

\section{Kalman-filter estimates of hysteresis}

The Kalman-filter technique (state-space modelling) offers a fruitful approach to estimating the Nairu because it is designed to identify an unobservable variable - like 
the Nairu - on the basis of assumptions made about the econometric properties of the variable and the economic interrelation between this variable and other observable variables. ${ }^{9}$ In what follows we model the Nairu as an nonstationary trend and estimate it simultaneously with a Phillips curve, the latter being the relationship through which the unemployment gap - the deviation of actual unemployment from the Nairu - affects inflation. We use a procedure presented by Kuttner (1994).

The unemployment gap $\left(u-u^{*}\right)$ is modelled as an $\operatorname{AR}(2)$ process $\frac{10}{10}$ and the instationarity of the Nairu $\left(u^{*}\right)$ as a local linear model. The Phillips curve ( $\pi$ stands for the inflation rate) is derived from a wage-setting equation and a price-setting equation as in Layard, Nickell, and Jackman (1991, pp. 361-396). The estimated system of equations is written below:

$$
\begin{aligned}
& \text { STATE EQUATIONS: } \\
& \left(u-u^{*}\right)_{t}=a r_{1}\left(u-u^{*}\right)_{t-1}+a r_{2}\left(u-u^{*}\right)_{t-2}+\epsilon_{t}^{u g a p} \\
& N A I R U_{t}^{\text {implicit }}=N A I R U_{t-1}^{\text {implicit }}+\text { trend }_{t}+\epsilon_{t}^{\text {nairu }} \\
& \text { trend }_{t}=\text { trend }_{t-1}+\epsilon_{t}^{\text {trend }} \\
& \text { DEFINITION EQUATION: } \\
& u_{t}=\left(u-u^{*}\right)_{t}+\left(N A I R U_{t}^{\text {implicit }}+\delta u_{t-1}\right) \\
& \text { PHILLIPS EQUATION: } \\
& \pi_{t}=\beta\left(u-u^{*}\right)_{t}+\gamma \mathbf{X}_{t}^{\text {phillips }}+\epsilon_{t}^{\pi} \\
& \text { memo }: u_{t}^{*}=N A I R U_{t}=N A I R U_{t}^{i m p l i c i t}+\delta u_{t-1}
\end{aligned}
$$

The first three equations specify the stochastic properties of the unobserved variables (state equations). The fourth equation is a definition, defining the unemployment rate as the sum of the unemployment gap and Nairu. The last equation (observation equation) is the Phillips curve that describes the interrelation between the unobserved unemployment gap and the observed inflation rate. The coefficient $\beta$ should be negative.

\footnotetext{
${ }^{9}$ Kalman-filter estimates of the Nairu of the OECD are found in Turner, Boone, Giorno, Meacci, Rae, and Richardson (2001); for the IMF see Laxton, Isard, Faruqee, Prasad, and Turtelboom (1998) and International Monetary Fund (2001, pp. 4-15) as well as Masi (1997) for the different methods used by the IMF to estimate the Nairu and potential output. Denis, McMorrow, and Röger (2002) provide the Kalman-filter estimate of the EU-Commission. Laubach (2001) estimates the Nairu for seven OECD countries using a Kalman filter. Unlike us, none of the authors use explicit exogenous variables in their estimations.

${ }^{10}$ This is a common way of modelling the unemployment gap, see for example Fabiani and Mestre (2001) and Apel and Jansson (1999).
} 
In addition to quantifying the Nairu, it is possible to use the state-space model to identify individual factors that determine it. The factor of influence explicitly dealt with here is the lagged unemployment rate measured by $\delta u_{t-1} . \mathbf{X}_{t}^{\text {phillips }}$ contains exogenous variables that explain the development of inflation rate (lags of inflation, change in the oil price and change in labour productivity growth)!11

We would have preferred to estimate the effect of long-run unemployment on the Nairu but due to data unavailability were unable to do so. Only the OECD provides long series of long-term unemployment for the Euro Area and these are inadequate since no adjustments are made as the number of countries included in the series are increased over time. The Eurostat time series begins only in 1993. To nonetheless test for the effect of long-term unemployment on the Nairu we also estimate the relationship for Germany, for which the time series is available and which has a weight of approximately $30 \%$ in the Euro Area.

Most of the data used are provided by the database of the ECB's Area Wide Model (AWM); they are on the quarterly basis and cover the period from 1970 to 2002!12 The data is seasonally adjusted and refers to the Euro Area with 12 member states, i.e. Germany, France, Italy, Spain, Netherlands, Austria, Portugal, Finland, Ireland, Belgium, Luxembourg and Greece. The time series for the price of oil (Brent, US-dollar) is taken from the IMF's International Financial Statistics; the series for a synthetic euro was constructed using the exchange rate series for the 12 member states provided by the IMF; the weights correspond to each country's share in the Euro Area's real GDP in 1995, as used in the AWM-database. The price of oil expressed in euro enters the Phillips curve as the year-over-year rate of change. Inflation is the year-over-year change in the consumer price index. Productivity growth is also expressed in terms of the year-over-year rate of change. Figure 4 in the appendix provides a synopsis of the data.

For the Kalman-filter estimation presented here, we tested one by one all lags of the unemployment rate (from -1 to -8). The fourth lag was the only one with significant explanatory power and no autocorrelation in the residuals. The constant was restricted to zero and the coefficients of the fourth and fifth lags of the change in the oil price were restricted. A LR-test (LR-statistic: 0.1905) did not rejected these restrictions. The estimation results were obtained without calibration of the variances of the residual series ${ }^{13}$ To ensure that the optimisation algorithm converged at a global maximum we performed sensitivity analyses by calibrating the variances. These confirmed that the

\footnotetext{
${ }^{11}$ The unit root tests are presented in Table 3 of the appendix.

12 The data constructed by Fagan, Henry, and Mestre (2001) can be found under http://www.ecb.int; a revised and updated version was directly obtained from the authors.

${ }^{13}$ We did not have to restrain the variances of the state equations, because the model has a sufficiently rich structure; cf. Fabiani and Mestre (2001), Richardson, Boone, Giorno, Meacci, Rae, and Turner (2000) and Apel and Jansson (1999).
} 
results without calibration are superior. The results are presented in Table 1 and Figure 114

Figure 1: Kalman-filter estimate of the Nairu and the unemployment gap in the Euro Area
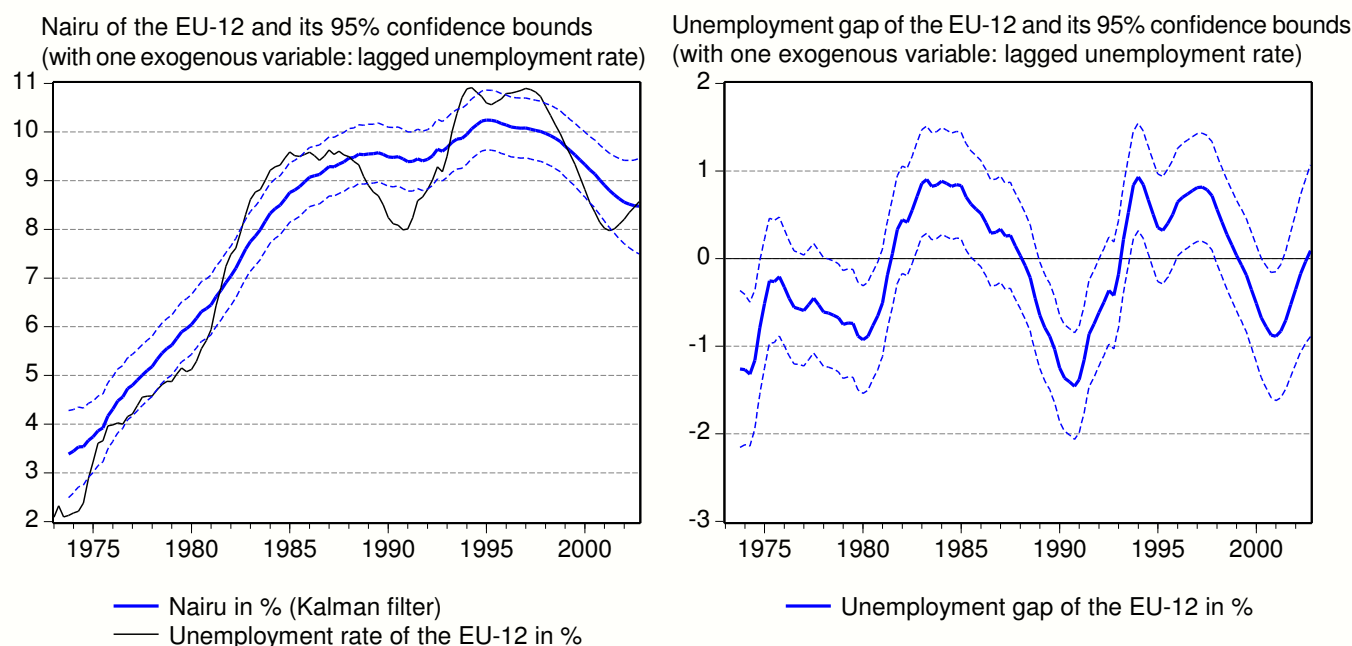

In the Kalman-filter estimate of the Nairu the coefficient of the lagged unemployment rate is 0.26 and significant, indicating the presence of hysteresis at the European level. This coefficient is comparable to that in Jaeger and Parkinson (1994) who apply a similar method and find hysteresis effects in the magnitude of between 0.22 and 0.18 for the UK and West Germany respectively. According to our estimate 1.6 percentage points of the increase in the Nairu between 1974 and 2002 can be attributed to hysteresis which is $31 \%$ of its total increase. In the two periods of increasing unemployment (1980-84 and 1991-93), hysteresis effects explain 45\%-65\% of the Nairu increase. In the last period of decreasing unemployment (1997-2000), hysteresis effects are able to explain $42 \%$ of the decrease of the Nairu.

14 The programme used for the Kalman-filter estimation is available free of charge under http://webfarm.jrc.cec.eu.int/. Questions concerning the programme can be addressed to the authors of this paper or to christophe.planas@jrc.it and alessandro.rossi@jrc.it (The European Commission, Joint Research Centre, Italy). 
Table 1: Output of the Kalman-filter estimate of the Nairu for the Euro Area with the unemployment rate as exogenous variable

Maximum likelihood estimates and statistics

Sample: 1973:2-2002:4 (119 obs.)

\begin{tabular}{|c|c|c|c|}
\hline Variables & Coefficients & s.e. & t-stat \\
\hline \multicolumn{4}{|l|}{ State equations } \\
\hline$a r_{1}$ & 1.7256 & 0.0683 & 25.2538 \\
\hline$a r_{2}$ & -0.7604 & 0.0659 & -11.5342 \\
\hline $\operatorname{Var}\left(\epsilon^{\text {nairu }}\right)$ & $1.97 \mathrm{E}-03$ & & \\
\hline $\operatorname{Var}\left(\epsilon^{\text {slope }}\right)$ & 1.04E-04 & & \\
\hline $\operatorname{Var}\left(\epsilon^{g a p}\right)$ & 9.28E-03 & & \\
\hline$u_{t-4}$ & 0.2649 & 0.0874 & 3.032 \\
\hline \multicolumn{4}{|c|}{ Phillips curve (observation equation) } \\
\hline Intercept & - & - & - \\
\hline$u-u^{*}$ & -0.1132 & 0.0495 & -2.2893 \\
\hline$\pi_{t-1}^{y o y}$ & 1.1961 & 0.0345 & 34.6504 \\
\hline$\pi_{t-4}^{y o y}$ & -0.5977 & 0.0697 & -8.574 \\
\hline$\pi_{t-5}^{\text {yoy }}$ & 0.3794 & 0.0553 & 6.8619 \\
\hline$\pi_{t}^{\text {oil,yoy }}$ & 0.0045 & 0.0006 & 7.806 \\
\hline$\pi_{t-2}^{o i l, y o y}$ & -0.0018 & 0.0007 & -2.695 \\
\hline$\pi_{t-4}^{\text {oil,yoy }}$ & -0.0033 & 0.0007 & -4.5642 \\
\hline$\pi_{t-5}^{\text {oil,yoy }}$ & 0.0033 & - & - \\
\hline$\Delta\left(\operatorname{prod}_{t-8}\right)$ & -0.098 & 0.0349 & -2.8082 \\
\hline di_1980q1 & 1.1399 & 0.2861 & 3.984 \\
\hline $\operatorname{Var}\left(\epsilon^{\text {Phillips }}\right)$ & 7.63E-02 & & \\
\hline$-2 * \log$-likelihood & -353.1044 & & \\
\hline \multicolumn{4}{|l|}{ Residual diagnostics } \\
\hline \multicolumn{4}{|l|}{ State equations } \\
\hline Ljung-Box Q(4) stat.= & 0.4177 & $\mathrm{p}$-value $=0.9810$ & \\
\hline Jarque-Bera stat. $=$ & 2.7787 & p-value $=0.2492$ & \\
\hline \multicolumn{4}{|c|}{ Phillips curve (observation equation) } \\
\hline Ljung-Box Q(4) stat.= & 7.7661 & $\mathrm{p}$-value $=0.1005$ & \\
\hline Jarque-Bera stat. $=$ & 2.6360 & p-value $=0.2677$ & \\
\hline
\end{tabular}

Variables:

$\pi^{y o y}$ : yoy-inflation rate in \% (based on the HICP)

$\pi^{\text {oil }, \text { yoy }}$ : yoy-growth rate in $\%$ of the oil price expressed in a synthetic $€$ prod: yoy-growth rate in $\%$ of the labour productivity

$u$ : unemployment rate in $\%$

di_1980q1: impulse dummy ( $=1$ at 1980Q1, 0 otherwise)

$\Delta: 1$ st difference $\left(\Delta X_{t}=X_{t}-X_{t-1}\right)$ 
The AR-coefficients $\left(a r_{1}\right.$ and $a r_{2}$ ) of the state equation (unemployment gap) imply a cycle length of 10.8 years! 15 The sum of the coefficients of the lagged endogenous variables is 0.9778 , the coefficient of the change in the oil price 0.0027 . Thus a 10 percentage-point increase in oil price inflation induces a long-term increase in inflation by 1.2 percentage points. The less drastic scenario of an increase in the oil price by 10 percent for two years and a subsequent return to its previous level causes inflation to temporarily increase by a maximum of 0.25 percentage points. The productivity growth rate has no effect on inflation in the long run. Nevertheless, an increase in productivity growth by 1 percentage point temporarily lowers the rate of inflation by a maximum of 0.16 percentage points.

In order to be able to use the long-term unemployment rate as an exogenous variable we also estimate the German Nairu. We use quarterly data for the period 19732002 mainly from the German Statistical Office and the German Bundesbank. The rate of long-term unemployment is provided by IAB on an annual basis and was converted to quarterly data with a quadratic algorithm that matches the annual average. We chained the West-German data with the unified German data in the first quarter of 1995, in order to exclude the transition period from the data. For times series like the German ones that are known to have a structural break at a particular date (1995Q1 in our case) Kalman-filter estimates with exogenous variables are particularly useful because a corresponding step dummy can be included in the Nairu equation. To illustrate this point we ran an estimation without exogenous variables. The Nairu was estimated as a local linear trend model which allows the Nairu to jump. Nonetheless the estimate was flawed, since the peak of the residuals at the time of the structural break was so pronounced, that the normality test was rejected. With the addition of a step dummy the log-likelihood value greatly increased (the LR-test statistic was equal to 30.26) and the residuals no longer exhibit outliers. It follows that estimating with exogenous variables is preferable because it adds flexibility to the modelling process. In our case we included a second step dummy for another (small) structural break in 1996Q1, which is purely the result of the conversion to quarterly data. The estimation results show that all three exogenous variables are significant and the residuals have good qualities, i.e. the normality tests are not rejected and there is no autocorrelation up to lag 4 .

The constant was restricted to zero. The coefficients of the lags of oil price inflation $\left(\pi^{\text {oil }, y o y}\right)$ and of the lagged second difference of productivity $(\Delta($ prod $)$ ) were restricted as well. The log-likelihood of a model without these restrictions was not significantly higher given an LR-statistic equal to 1.812. The null hypothesis that the restrictions are valid thus cannot be rejected even at the $10 \%$-level (critical values are drawn from a Chi-distribution with 4 degrees of freedom).

\footnotetext{
${ }^{15}$ The equation for calculating the cycle length is given in Jaeger and Parkinson (1994, p. 338).
} 
The estimation results below were obtained without calibrating the residuals' variances. We did, however, try some calibrations to ensure that the optimisation algorithm converged at a global maximum of the log-likelihood, but were unable to find a superior estimation in the sense of a higher value of the log-likelihood. From the estimated AR-coefficients of the unemployment gap, a cycle of 34 quarters ( 8.5 years) can be deduced. The sum of the coefficients of the lagged endogenous variables is 0.9473 , the one of the oil price 0.0035 . Thus a 10-percentage point increase in oil price inflation causes inflation to rise by 0.7 percentage points in the long run. Neither productivity growth nor its acceleration rate has an effect on inflation in the long run - the coefficients cancel each other. Nevertheless a one-percentage-point increase in productivity growth and in its acceleration rate temporarily lower inflation by a maximum of 0.07 percentage points and 0.06 percentage points respectively.

The effect of long-term unemployment is estimated at 0.82 . The coefficient varies somewhat depending on whether the step dummy for 1996Q1 is included, not included or replaced by an impulse dummy. Nonetheless, in each case it is significant and above 0.5 , the lowest coefficient being 0.56. The estimate presented is the best one in terms of log-likelihood and the properties of the residuals. The magnitude of 0.8 implies an increase in the Nairu due to hysteresis of 2.8 percentage points between 1974 and 2002 which amounts to $37 \%$ of its total increase in that period. In the two periods of rising unemployment (1980-1983 and 1992-1997), hysteresis effects account for $60 \%$ of the Nairu's increase. In periods of decreasing unemployment (1984-1991 and 1998-2000), hysteresis effects can explain an even greater part of the change in the Nairu. In the first period hysteresis effects account for almost 0.8 percentage points of the Nairu's decline; in the second period hysteresis effects alone would have caused the Nairu to fall by 0.7 percentage points, whereas it actually declined by only 0.2 percentage point implying that other factors only implicitly accounted for in the estimate caused an upward movement in the Nairu.

How do the estimates for the Euro Area and Germany compare? Given a share of long-term unemployment in total unemployment of roughly one-third, the German coefficient of 0.8 would imply a coefficient of 0.25 for lagged unemployment in the Nairu equation. This is essentially the same as the coefficient of 0.26 for the Euro Area, implying that lagged unemployment is a good proxy for long-term unemployment. 
Figure 2: Nairu and unemployment gap for Germany

Nairu of the EU-12 and its $95 \%$ confidence bounds (with one exogenous variable: lagged unemployment rate)

Unemployment gap of the EU-12 and its $95 \%$ confidence bounds

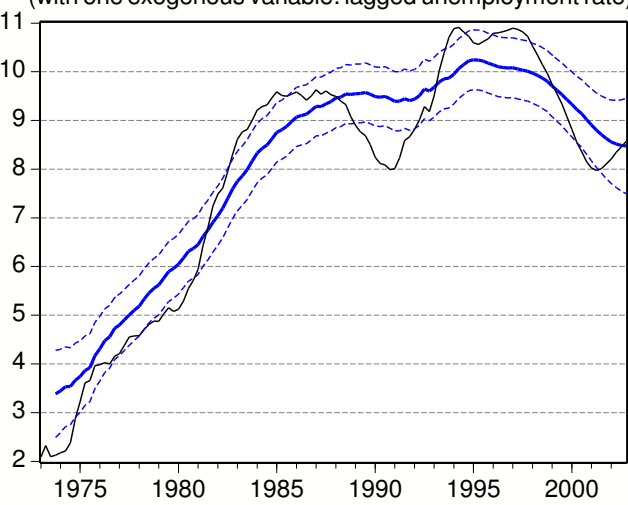
with one exogenous variable: lagged unemployment rate)

1975

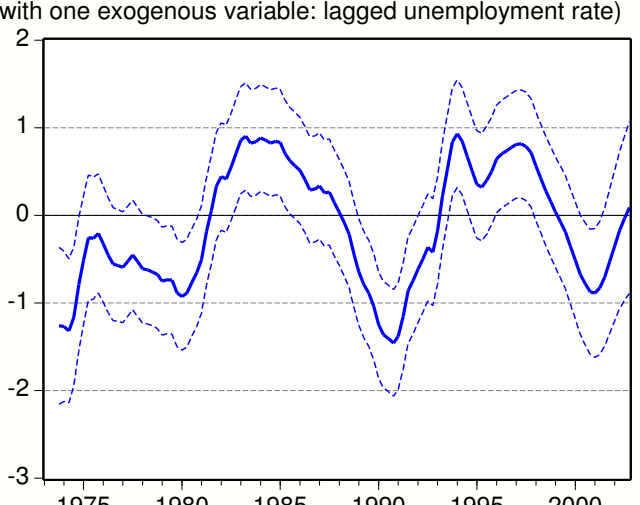

- Nairu in \% (Kalman filter)

Unemployment rate of the EU-12 in \%

- Unemployment gap of the EU-12 in \% 
Table 2: Output of the Kalman-filter estimate for Germany with the long-term unemployment rate as exogenous variable

\begin{tabular}{|c|c|c|c|}
\hline \multicolumn{4}{|c|}{$\begin{array}{l}\text { Maximum likelihood estimates and statistics } \\
\text { Sample: } 1973: 1-2002: 4 \text { (120 obs.) }\end{array}$} \\
\hline Variables & Coefficients & s.e. & t-stat \\
\hline \multicolumn{4}{|l|}{ State equations } \\
\hline$a r_{1}$ & 1.695 & 0.0691 & 24.5194 \\
\hline$a r_{2}$ & -0.7433 & 0.0658 & -11.2929 \\
\hline $\operatorname{Var}\left(\epsilon^{\text {nairu }}\right)$ & $2.76 \mathrm{E}-03$ & & \\
\hline $\operatorname{Var}\left(\epsilon^{\text {slope }}\right)$ & $9.48 \mathrm{E}-05$ & & \\
\hline $\operatorname{Var}\left(\epsilon^{g a p}\right)$ & $1.65 \mathrm{E}-02$ & & \\
\hline ltur & 0.821 & 0.2679 & 3.065 \\
\hline d95q1 & 1.0676 & 0.1241 & 8.6021 \\
\hline d96q1 & 0.3311 & 0.132 & 2.5075 \\
\hline \multicolumn{4}{|c|}{ Phillips curve (observation equation) } \\
\hline Intercept & 0 & - & - \\
\hline Unemployment gap & -0.1886 & 0.0515 & -3.6606 \\
\hline$\pi_{t-1}^{y o y}$ & 1.0457 & 0.0417 & 25.0617 \\
\hline$\pi_{t-4}^{\text {yot }}$ & -0.4478 & 0.0878 & -5.1002 \\
\hline$\pi_{t-5}^{y o y}$ & 0.3494 & 0.0721 & 4.8472 \\
\hline$\pi_{t}^{\text {oil,yoy }}$ & 0.0035 & 0.0007 & 5.117 \\
\hline$\pi_{t-2}^{\text {oil,yoy }}$ & -0.0035 & - & - \\
\hline$\pi_{t-3}^{\text {oil,yoy }}$ & 0.0035 & - & - \\
\hline$\Delta\left(\operatorname{prod}_{t-8}\right)$ & -0.0588 & 0.02 & -2.9368 \\
\hline$\Delta\left(\operatorname{prod}_{t-1}\right)$ & 0.0588 & - & - \\
\hline $\operatorname{Var}\left(\epsilon^{\text {Phillips }}\right)$ & $1.16 \mathrm{E}-01$ & & \\
\hline$-2 * \log$-likelihood & -244.2605 & & \\
\hline \multicolumn{4}{|l|}{ Residual diagnostics } \\
\hline \multicolumn{4}{|l|}{ State equations } \\
\hline Ljung-Box Q(4) stat.= & 0.6481 & \multirow{2}{*}{\multicolumn{2}{|c|}{$\begin{array}{l}\mathrm{p} \text {-value }=0.9576 \\
\mathrm{p} \text {-value }=0.4901\end{array}$}} \\
\hline Jarque-Bera stat. $=$ & & & \\
\hline \multicolumn{4}{|c|}{ Phillips curve (observation equation) } \\
\hline Ljung-Box Q(4) stat.= & 6.2662 & $\mathrm{p}$-value $=0.1801$ & \\
\hline Jarque-Bera stat.= & & p-value $=0.5788$ & \\
\hline
\end{tabular}

\footnotetext{
Variables:

$\pi^{y o y}$ : German yoy-inflation rate in \% (from the HCIP)

$\pi^{\text {oil,yoy }}$ : German yoy-growth rate in $\%$ of the oil price, expressed in DEM.

prod: German yoy-growth rate in $\%$ of productivity (defined as real GDP divided by employment).

$\Delta: 1$ st difference $\left(\Delta X_{t}=X_{t}-X_{t-1}\right)$

All variables are seasonally adjusted and apply to West Germany up to 1994 and unified Germany thereafter.
} 


\section{Conclusion: Interpreting the Nairu and hysteresis in the Euro Area}

During the past 30 years the Nairu has changed markedly in the Euro Area. In the mid-seventies the Nairu was slightly below $3 \%$, by the mid-eighties it had risen to $9.0 \%$ and, after rising further in the first half of the 1990s to more than $10 \%$, in 2002 it measured at $8.6 \% .16$ Our analysis also shows that the unemployment gap and Nairu are not independent of each other. To a certain extent the structure of unemployment is hardened or loosened so that the unemployment gap closes as simultaneously the Nairu rises or falls.

The estimation results show that hysteresis effects were already starting to emerge in the second half of the seventies but became a more influential factor determining the Nairu in the eighties. Unemployment rose from $5.4 \%$ to $9.5 \%$ between 1980 and 1985 leading to hysteresis effects in the magnitude of 1.1 percentage points. This accounts for more than $40 \%$ of the entire increase in the Nairu during the first half of the eighties. During this period the increase of actual unemployment was at least in part the result of a restrictive monetary policy stance ${ }^{\sqrt{17}}$ that caused the short-term real interest rate to rise from $1 \%$ at the beginning of 1980 to $5.4 \%$ in 1989 thereby reducing economic growth. In the first half of the 1990s a further increase in the Nairu by 1.3 percentage points to $10.4 \%$ coincided with an increase in real interest rates by around 2 percentage points. Hysteresis can account for more than $50 \%$ of the 0.7 percentage-point increase in the Nairu during this period.

Since the mid-1990s the Nairu has declined by 1.7 percentage points. This decline can also be in part explained by hysteresis, albeit in the opposite direction. It contributed 0.6 percentage point to the Nairu's reduction. In this period interest rates declined by 1.2 percentage points.

Our hypothesis is that in addition to exogenous shocks as well as institutions,

\footnotetext{
${ }^{16}$ Like ours most other economic regressions show a marked reduction in the Nairu since 1996; see for example International Monetary Fund (2001, p. 4). International Monetary Fund (2001, p. 8) uses the Kalman-filter technique (without explicit exogenous variable) to derive a no-supply-shock Nairu that has hovered around $9.5 \%$ since the first quarter of 1983 and a Nairu with supply shocks that increased from $8.5 \%$ (1983) to almost $11 \%$ in 1994 and then slowly diminished to reach slightly more than $8 \%$ in the year 2000. An unemployment gap of $1 \%$ goes hand in hand with an output gap of $1.7 \%$. The Phillips-curve relation shows that inflation is reduced by 0.5 percentage points in the first year in which the unemployment rate exceeds the Nairu by $1 \%$. The OECD's Nairu (without supply shocks, Turner, Boone, Giorno, Meacci, Rae, and Richardson, 2001) climbs from 5.5\% in 1980 to $9.2 \%$ in 1995 and then falls to reach $8.8 \%$ in 1999 . The coefficients of the unemployment gap in the Phillips curves of the individual countries (Germany and France 0.2 , Italy 0.3$)$ and for the oil price $(0.1 \%)$ have of similar magnitude as ours.

${ }^{17}$ International Monetary Fund (1996, chap. 6, pp. 100-131)
} 
macroeconomic policy and hysteresis were instrumental in causing the marked increase in the Nairu since the mid-seventies of the last century.

Whereas a slowdown in productivity growth, the oil price shocks and an increase in international real interest rates was experienced by all countries - albeit to different degrees -, a marked difference between the monetary policies pursued by the individual central banks can be observed. The US Federal Reserve lowered interest rates rapidly when an economic downturn presented itself thus containing the strength and duration of a given crisis. ${ }^{18}$ In consequence an increase in unemployment remained a temporary phenomenon. In contrast, monetary policy in the countries of the current Euro Area maintained a restrictive stance longer. Economic downturns were more pronounced and the weak growth was not compensated for in subsequent years. As a result the growth path in the European economies was lower than would have corresponded to their production possibilities.

A major difference between studies dealing with the development of unemployment in EU countries is whether or not they consider this contrast in the monetary policy reaction: Layard, Nickell, and Jackman (1991) and Clarida, Galí, and Gertler (1998), for example, analyse the effects of shocks and in this context discuss the level of world interest rates; they do not, however, examine the macroeconomic policies in the individual countries. In contrast, Fitoussi, Jestaz, Phelps, and Zoega (2000, pp. 237-310), Ball and Mankiw (2002), Ball (1999) and Blanchard and Katz (1997) relate the marked increase in unemployment and the fact that it remained high to the restrictive stance of monetary policy. Our results concerning hysteresis in the Euro Area support the hypothesis put forth by Ball (1999) that monetary policy played a decisive role in whether unemployment hardened in individual countries:

"In some countries, such as the United States, the rise in unemployment was transitory; in others, including many European countries, the Nairu rose and has remained high ever since. I argue that the reaction of policymakers to the early-1980s recessions largely explain these differences. ... In countries where unemployment rose permanently, it did so because policy remained tight in the face of the 1980s recessions."

Ball (1999, p. 190)

Monetary policy certainly had to act restrictively to contain the inflationary pressures of the seventies and to bring inflation back to acceptable levels. A reduction in inflation is brought about through an increase in unemployment, so that a temporary

\footnotetext{
${ }^{18}$ The Fed has acted in this fashion active since the late seventies. During the seventies it had been more passive and thus contributed to the simultaneous increase in inflation and unemployment; cf. Beyer and Farmer (2002).
} 
increase in the rate of unemployment was unavoidable during the eighties. However, the pressure unemployment exerts on inflation diminishes over time. Unlike the central banks in Europe, the US Federal Reserve took this point into consideration with the consequence that the increase in unemployment remained a temporary phenomenon in the United States, whereas it hardened in the countries of the Euro Area thus becoming a more permanent phenomenon. This is evident when one compares the timing of policy reaction, inflation slowdown and unemployment increase around the time of recessions. A correlation test for the period 1980 until 2001 also shows that whereas the Fed reacted promptly to a change in unemployment, the European central banks hardly reacted to changes in unemployment at all.19

Figure 3 shows these different monetary policy reactions in the US on the one hand and in the Euro Area on the other. The Federal Reserve lowered nominal interest rates as unemployment started to rise, the European central banks stayed on a restrictive course much longer. The gain in the shape of an additional reduction in inflation was small. This is not surprising as econometric analyse ${ }^{20}$ indicate that the disinflationary effect of unemployment decreases over time. Hysteresis provides an explanation for this reduced effect of unemployment on inflation. It also lends support to the hypothesis that macroeconomic policy can have long-term effects. In the words of Solow:

"... the long-run aggregate supply curve may be vertical, but its location is endogenous to macroeconomic policy." $\quad$ (Solow 1998, p. 11)

\footnotetext{
19 The correlation between short-term nominal interest rates and the unemployment rate (both in first differences) is significantly negative for lags 0 and 1 in the case of the United States; in the case of the Euro Area only lag zero is significant and the coefficient is much smaller; see also the empirical analysis by Ball (1999).

${ }^{20}$ Impulse-response analyses show that in the Euro Area an increase in unemployment lowers inflation from the $3^{r d}$ to the $12^{\text {th }}$ quarters; in the United-States the effect is significant only in the first seven quarters.
} 
Figure 3: Monetary policy reactions to unemployment in the Euro Area and in the United States
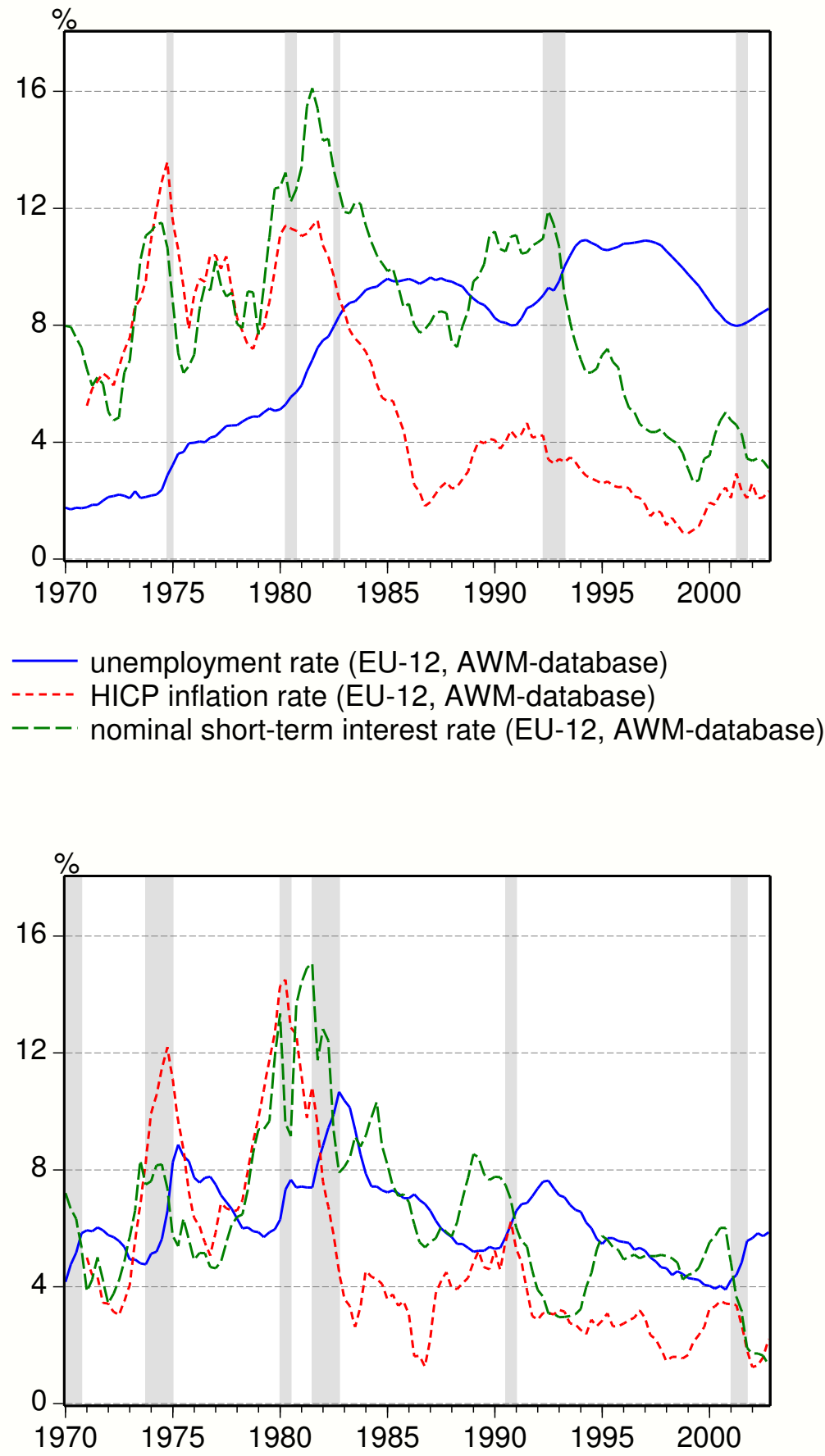

- unemployment rate (USA, Federal Reserve of St-Louis)

--.-- CPI inflation rate (USA, Federal Reserve of St-Louis)

-- - nominal 3 months interest rate (USA, Federal Reserve of St-Louis)

The shaded areas mark recessions

(dating according to our own calculations and the NBER respectively) 


\section{References}

Akerlof, G. A., W. T. Dickens, And G. L. Perry (2000): "Near-Rational Wage and Price Setting and the Long-Run Phillips Curve," Brookings Papers on Economic Activity, 1, 1-60.

Amable, B., J. Henry, F. Lordon, and R. Topol (1995): "Hysteresis revisited: A Methodological Approach," in The Natural Rate of Unemployment. Reflections in 25 years of the Hypothesis, ed. by R. Cross, chap. 9, pp. 153-180. Cambridge University Press, Cambridge.

Apel, M., And P. Jansson (1999): "A Theory-Consistent System Approach for Estimating Potential Output and the NAIRU," Economic Letters, 64(3), 271-275.

BALL, L. (1999): "Aggregate Demand and Long-Run Unemployment," Brookings Papers on Economic Activity, 1999(2), 189-251.

BALL, L., AND N. G. MANKIW (2002): "The NAIRU in Theory and Practice," Journal of Economic Perspectives, 16(4), 115-136.

BEAN, C. R. (1997): "The role of demand-management policies in reducing unemployment," in Unemployment Policy. Government Options for the Labour Market, ed. by D. J. Snower, and G. de la Dehesa, pp. 83-111. CEPR, Cambridge University Press, Cambridge.

Beyer, A., And R. E. A. FARmer (2002): “Natural Rate Doubts,” Working Paper 121, ECB.

BlanchaRd, O. J., AND P. DiAmond (1994): "Ranking, Unemployment Duration, and Wages," The Review of Economic Studies, 61(3), 417-434.

Blanchard, O. J., And L. F. Katz (1997): "What We Know and What We Do Not Know About the Natural Rate of Unemployment," Journal of Economic Perspectives, 11(1), 51-72.

BlanchaRD, O. J., AND L. H. Summers (1991): "Hysteresis and Unemployment," in New Keynesian Economics. Coordination Failures and Real Rigidities (Vol. 2), ed. by N. G. Mankiw, and D. Romer, pp. 235-243. MIT Press, London.

Blanchard, O. J., AND J. WolfERS (2000): "The Role of Shocks and Institutions in the Rise of European Unemployment: the Aggregate Evidence," The Economic Journal, 110(462), C1-C33.

Clarida, R., J. Galí, and M. Gertler (1998): "Monetary Policy Rules in Practice: Some International Evidence," European Economic Review, 42(6), 10331067. 
- (1999): "The Science of Monetary Policy: A New Keynesian Perspective," Journal of Economic Literature, 37(4), 1661-1707.

CROSS, R. (1995): "Is the Natural Rate Hypothesis Consistent with Hysteresis?," in The Natural Rate of Unemployment. Reflections in 25 years of the Hypothesis, ed. by R. Cross, chap. 10, pp. 181-200. Cambridge University Press, Cambridge.

Denis, C., K. McMorrow, And W. Röger (2002): "Production Function Approach to Calculating Potential Growth and Output Gaps - Estimates for the EU Member States and the US," Economic Papers 176, European Commission.

Fabiani, S., And R. Mestre (2001): "A System Approach for Measuring the Euro Area NAIRU,” Working Paper 65, ECB.

Fagan, G., J. Henry, and R. Mestre (2001): “An Area-Wide Model (AWM) for the Euro Area," Working Paper 42, ECB.

Fitoussi, J.-P., D. Jestaz, E. S. Phelps, and G. Zoega (2000): "Roots of the Recent Recoveries: Labor Reforms or Private Sector Forces?," Brookings Papers on Economic Activity, I, 237-311.

IM, K., M. H. PESARAN, AND Y. SHIN (2003): “Testing for Unit Roots in Heterogeneous Panels," Journal of Econometrics, 115(1), 53-74.

InTERnAtional Monetary Fund (1996): World Economic Outlook. IMF, Washington D.C., Fall edn.

(2001): "Monetary and Exchange Rate Policies of the Euro Area: Selected Issues," Country report 1/201, IMF.

JAEGER, A., AND M. PARKInSON (1994): "Some Evidence on Hysteresis in Unemployment Rates," European Economic Review, 38(2), 329-342.

JoHAnsen, K. (1995): “Norvegian Wage Curves," Oxford Bulletin of Economics and Statistics, 52(2), 229-247.

KATZNER, D. W. (1993): "Some notes on the role of history and the definition of hysteresis and related concepts in economic analysis," Journal of Post Keynesian Economics, 15(3), 323-345.

Kuttner, K. N. (1994): "Estimating Potential Output as a Latent Variable," Journal of Business \& economic Statistics, 12(3), 361-368.

LAUBACH, T. (2001): "Measuring the NAIRU: Evidence from seven economies," The Review of Economics and Statistics, 83(2), 218-231. 
Laxton, D. M., P. Isard, H. Faruqee, E. S. Prasad, and B. Turtelboom (1998): "Multimod Mark III: The Core Dynamic and Steady State Model," Occasional Paper 164, IMF.

Layard, R., S. Nickell, And R. JACKMAn (1991): Macroeconomic Performance and the Labour Market. Oxford University Press.

LeÓN-Ledesma, M. A. (2002): "Unemployment Hysteresis in the United States and the EU: A Panel Approach,” Bulletin of Economic Research, 54(2), 95-103.

LEÓN-Ledesma, M. A., ANd P. MCAdAM (2004): "Unemployment, Hysteresis and Transition," Scottish Journal of Political Economy, 51(3), 377-401.

LINDBECK, A. (1995): "Welfare State Disincentives with Endofenous habits and Norms," Scandinavian Journal of Economics, 97(4), 477-494.

LocKWood, B. (1991): "Information Externalities in the Labour Market and the Duration of Unemployment," The Review of Economic Studies, 58(4), 733-753.

Machin, S., And A. MAnning (1999): "The Causes and Consequences on Longterm Unemployment in Europe," in Hanbook for Labour Economics, ed. by O. C. Ashenfelter, and D. Card, vol. 3C, Chap. 47, pp. 3085-3139. North-Holland.

Mankiw, N. G. (1985): "Small Menu Costs and Large Business Cycles: A Macroeconomic Model of Monopoly," The Quarterly Journal of Economics, 100(2), 529537 ,

Neu abgedruckt in Mankiw und Romer (1991), Vol. I.

(2001): "The Inexorable and Mysterious Tradeoff Between Inflation and Unemployment," The Economic Journal, 111(471), C45-C61.

MASI, P. R. D. (1997): "IMF estimates of Potential Output: Theory and Practice," in Staff Studies for the World economic Outlook, pp. 40-46. IMF, Washington D.C.

McCallum, B. T. (2001): "Should Monetary Policy Respond Strongly to Output Gaps?," American Economic Review. Papers and Proceedings, 91(2), 258-262.

PISSARIDES, C. A. (1992): "Loss of Skill During unemployment and the Persistence of Employment Shocks," The Quaterly Journal of Economics, 170(4), 1371-1391.

Richardson, P., L. Boone, C. Giorno, M. Meacci, D. Rae, and D. Turner (2000): "The Concept, Policy Use and Measurement of Structural Unemployment: Estimating a Time Varying NAIRU Across 21 OECD Countries," Working Paper 250, OECD.

RøED, K. (1997): "Hysteresis in Unemployment," Journal of Economic Surveys, 11(4), 389-418. 
SALEMI, M. K. (1999): "Estimating the Natural Rate of Unemployment and Testing the Natural Rate Hypothesis," Journal of Applied Econometrics, 14(1), 1-25.

Shapiro, C., AND J. E. STIGlitz (1984): "Equilibrium Unemployment as a Worker Discipline Device," The American Economic Review, 74(3), 433-444.

Solow, R. M. (1998): "How cautious must the fed be?," in Inflation, Unemployment, and Monetary Policy, ed. by B. M. Friedman, pp. 1-28. The MIT Press, Cambridge, USA.

TAYlOR, J. B. (1997): “A Core of Practical Macroeconomics," The American Economic Review, Papers \& Proceedings, 87(2), 233-235.

Turner, D., L. Boone, C. Giorno, M. Meacci, D. Rae, and P. Richardson (2001): "Estimating the Structural Rate of Unemployment for the OECD Countries," OECD Economic Studies, II(33), 171-216.

WeitZMAN, M. L. (1982): "Increasing returns and the Foundations of unemployment theory," Economic Journal, 92(368), 787-804. 


\section{Appendix}

Figure 4: Presentation of the data
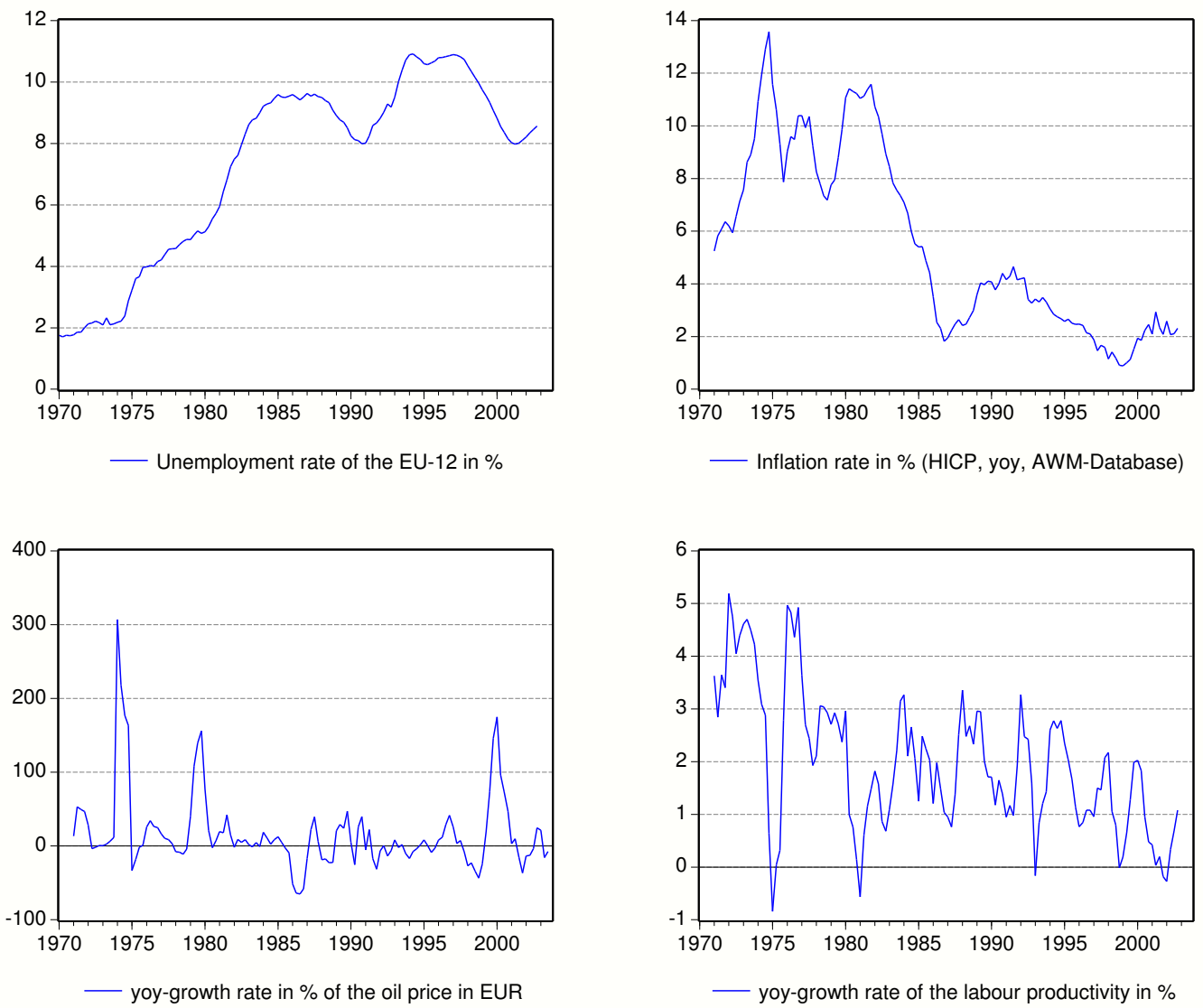
Table 3: Unit root tests for the EU-12

\begin{tabular}{|c|c|c|c|c|c|c|}
\hline variable name & sample & test type $^{1}$ & lag-length ${ }^{2}$ & deterministic & test-stat & test-prob ${ }^{3}$ \\
\hline \multirow[t]{4}{*}{ inflation } & $1970-2002$ & $\mathrm{ADF}$ & 10 & $\mathrm{c}$ & -1.47 & 0.543 \\
\hline & & $\mathrm{ADF}$ & 6 & $\mathrm{c}$ & -1.37 & 0.595 \\
\hline & & ERS & 10 & c & -1.57 & $* * *$ \\
\hline & & ERS & 6 & $\mathrm{c}$ & -1.43 & $* * *$ \\
\hline \multirow{4}{*}{$\begin{array}{l}\text { unemployment } \\
\text { rate }\end{array}$} & $1970-2002$ & $\mathrm{ADF}$ & 5 & $\mathrm{c}$ & -1.92 & 0.321 \\
\hline & & $\mathrm{ADF}$ & 2 & $\mathrm{c}$ & -1.93 & 0.319 \\
\hline & & ERS & 5 & $\mathrm{c}$ & -0.18 & $* * *$ \\
\hline & & ERS & 2 & $\mathrm{c}$ & -0.22 & $* * *$ \\
\hline \multirow{4}{*}{$\begin{array}{l}\text { oil price } \\
\text { index }\end{array}$} & $1970-2003$ & $\mathrm{ADF}$ & 4 & $\mathrm{c}$ & -2.08 & 0.254 \\
\hline & & $\mathrm{ADF}$ & 0 & $\mathrm{c}$ & -1.88 & 0.34 \\
\hline & & ERS & 5 & $\mathrm{c}$ & -0.57 & $* * *$ \\
\hline & & ERS & 0 & $\mathrm{c}$ & -0.71 & $* * *$ \\
\hline \multirow{6}{*}{$\begin{array}{c}\text { dlprod } \\
\text { (productivity } \\
\text { growth) }\end{array}$} & $1970-2002$ & $\mathrm{ADF}$ & 0 & $\mathrm{c}$ & -9.6 & 0 \\
\hline & & ERS & 9 & $\mathrm{c}$ & 0.18 & $* * *$ \\
\hline & & ERS & 3 & $\mathrm{c}$ & -1.18 & $* * *$ \\
\hline & & $\mathrm{ADF}$ & 0 & $\mathrm{c}$, trend & -10.66 & 0 \\
\hline & & ERS & 9 & $\mathrm{c}$, trend & -1.45 & $* * *$ \\
\hline & & ERS & 1 & $\mathrm{c}$, trend & -4.93 & \\
\hline
\end{tabular}

${ }^{1}$ ADF: Augmented-Dickey-Fuller test; ERS: Elliott-Rothenberg-Stock DF-GLS test

2 The lag-length was chosen along AIC and SC criteria. When they indicate different laglengths, both were reported.

$3 *, * *, * * *=$ accept $\mathrm{H} 0$ at $1 \%, 5 \%, 10 \%$

Thus inflation, the unemployment rate and the oil price can be seen as I(1) variables. This is also true for productivity growth, albeit with weaker evidence. 
Publisher: Hans-Böckler-Stiftung, Hans-Böckler-Str. 39, 40476 Düsseldorf, Germany

Phone: +49-211-7778-331, IMK@boeckler.de, http://www.imk-boeckler.de

IMK Working Paper is an online publication series available at:

http://www.boeckler.de/cps/rde/xchg/hbs/hs.xls/31939.html

\section{ISSN: 1861-2199}

The views expressed in this paper do not necessarily reflect those of the IMK or the Hans-Böckler-Foundation.

All rights reserved. Reproduction for educational and non-commercial purposes is permitted provided that the source is acknowledged.
Hans Böckler Stiftung

Fakten für eine faire Arbeitswelt. 